\title{
ANALISIS HUKUM TERHADAP ASURANSI KENDARAAN BERMOTOR BAGI PEMILIK KENDARAAN SEBAGAI TERTANGGUNG
}

\section{Nurhaedah \\ Universitas Muslim Indonesia}

\section{Alestrak:}

Asuransi ketwarkan bermotor merupakan asuransi khusus scbagai pertangyungan atau asuranst apabila kendarash itu mendapst kecelakaan dan atau hilang schingga memberikan jaminan kepada megoth masyarakat yang tertimpa musibsh kecelaksan lalu lintas di luar kesalahannya sendiri kartra pengzuna kecdaraan pribsdi yang ditampanginya, lilang atau cacacnya kendarasa adalah merupakan suatu peristiwa yang tidak disengaja acaupun tidsk fisangka-sangka terjsidi. Pengaturan asamansi dalam KUHD mengutamakan segi keperdatasin yeng didasarkan poda perjanjian aecara teranegung dengan pensungeung. Perjanjiant tersebut menimbalkan kewsjibun das hak tertanggung dan penanggung secara timbal balik. Sebagai perjagjian khusas, asuransi dibuat secara tertulis dalam akta yang disebul polis asuransi. KUHD mengutamakan pengaturan asaransi dari segi keperdata2n, sedangkan Undang. Undang No 40 Tahun 2014 tentang Perasuransian mengutamakan pengaturan asuransi dari segi bisnis dan publik administratif, Pengaturan lebih lanjut kepada Oteritas Jasa Keuangen dalam hal pengaluran Jan pengawasan sebagai upaya pelindungan konsumen jass perasuransian untuk penyelenggaran, pengatursin, dis pengawasan industri perasuransian.

\section{PENDAHULUAN}

Isdonesia sebagai sabah satu negara yang selang berkembeng, yang sedsing giatgialnya melaksanskan pembangunan di segala bilang yang dilaksanakan stara berkesinansbungan baik di dacrah maspos di pusat, untuk mexujudikan masyarakat yang solil dan makmur. Di sisi lain Dembangunan sidak luput dafi bereagai zesiko yang daps. menggangu hasil pembangunan yang telah dicapai selags: penunjang pelzksanann pembangunan, dibutuhken meds traspoctasi youg memamadal, sebogai sarana untuk menghubungkan antana tempat yang satu dengan tempat yang lainnya yang memberikan efektifitas terhadap aktivitas masyarakar, hal ini dapat dilihus pada Peningkatan jumak kendaraan benaboor yang senus terjadi, dari dats Gari Gabungan Industri Kendaran Bermotor Indonesia (Gaikieso) dan Asoshasi Industri Sepeda Mocor Indonesin (AISI) menunjukkan terdapsat perambahan 8,1 juta unit kendaraan podz tahun 2010 yang ténliri dari 7,4 juta kendarasas roda dua dan 764,7 ribu kendaraan roda empat dari berbagai tipe Sehingga 
populasi kendarasan psda cahan 2010 sebesar 78,8 juta unit. Jamlah kendaraan di Indonesia dalam beberapa tahun terakhir terus bertumbah secarn signifikan. Data Organiswian Intomariante des Construcrears d'Alomobiles (OICA) menuajukkan pada tahun 2010, produksi kendaraan roda empat di Indonesia meningkat sebesar $51,1 \%$ dibending tahua sebciumnya. Koedisi ini menempatkan Indonesia dalam posisi kedua setelah Thailand dzlam hal prodaksi kendaraan roda empst di kawasan Ásia Oceania.

Berdasarkan data diatas maka peningkatan peran industri perasuransian dalam mendorong pernbangunan nasicosl terjadi apabila industri perasuransian dapat lebīh mendukung masyaraken dalam menghadapi risiko yang dihsdapi sehari-hari dan pada sant mereka memulai dan menjalankan kegiatan usahz. Untuk itu Objek Asaransi di Indonesia hanya dapat diasuransikan pada Penusahsan Asuransi atau Perusahaan Asuransi Syariah di Indonesia dan penutupan Ohjek Asuransi tersebut harus memperhatikan optimalisasi kapasítas Perusahaan Asuransi, Perusahsan Asuransi Syariah, perusahaan reasuransi, dan perusahasan reasurnnsi syarish dalam negeri, untuk mengimbangi kebijakan ini, Pemerintah dan'atau Otoricss Jasa Keasngan melakukan upaya untuk mendorong peningkatan kapasitas asuransi dan ressuransi dalam negeri. Usaha Perasursinsian telah diatur dalem Undang-Undang Nomor 40 Tahun 2014 tentans Perasuransian, pengaturan pengelolsan kekayaan dan kewajiban Perusahaan
Asuransi, Perusahaan Asuransi Syaniah, Perusahsan Reasuransi, dan Perusahaan Reasuransi Syariah, akan menemtukan besar atau kecilnya peran industri perasuransian tersebut. Pengaturan dzlam Undang-Undang ini jugs mencerminkan perhatian den dukungan besar bagi upaya pelindungan kensumen jasa perasuransian, upaya antisipasi lingkungan perdagangan jasa yang lebih terbuks pads tingkar regiconal, dan penyesuaian terhadap praktik terbsik best pnoctices) di tingkat internasional untuk panyelenggaran, pengaturan, dun pengawasan industri perasuransian. Dalant industri perasuransian, baik secara nasional maupun global, terjadi perkembangan yang pesat yang dilandai deagan meningkatnya volume usaha dan sesara ofomatis bertambahnya pemantastan layanan jasa perasuransian oleh masyamat. Layanan jasa perasuransias pun semskin bervariasi sejalan dengan perkembangan kebutuhan masyarakat akan kendarann roda empat yang ditunjang oleh pengelolanan risiko dan pengelolaan investasi yang semakin tidak terpisahkan, baik dalam kehidupan pribadi maupun dalam kegiatan usaha.

Di

Indonesia

pengeunaan hasilhasil produksi teknologi yang tinggi dibidang slat angkut pesat sekali, meskipun yang menikmati hasil produksi tersebat baru sebhagian golongan mesyarakat sasja. Produksi kendaraan roda empat saat ini tidak terbilang jumlahnya disebabkan persaingan harga dan 
kualitas kendarasin pribodi mappun kendaraan umum sebagai alat angkut dari tahan $\mathrm{ke}$ tahun semakin meningkat jumlahnya, hal ini dapat dilihat pods lingginya minat masyarakat terhadap kepemilikan kendaraan roda empot, salah sata faktoenya karena adanya berbagai macam fasilitas yang ditawarkan oleh perusahaan asuransi sabagai benluk kerja sama antarn dealer dengan pilkak asuransi. Salah satu tujusnnya adalah menangesulangi resiko yang terjadi selama jangka waktu cicilan kendaraan tersebut khususnys perusahaan asuransi yang berhubungan dengan kegiatan memberikan jaminan ana tangungan kepada sesecrang staa kepada suatu aset tertentu yang; terkena musibah atau peristiwa yang belum pasti terjadi. Usaha untak mengatași risiko akibat persaingan jual beli kendaraan bermotor dilakukan dengan berbagai macam cara antara lain dengan mengzdakan perjanjian asuransi yang mempunyai tujuan mengalihkan sebagian atau seluruh risiko kepada pihak lain yang mampu menerims atata dengan mengganti kerugian kepada pembeli atau pernakaian dengan menggenti kerugian kepsds orang yang menghadapi risiko itu. Dengan adanya berbagai jenis pertanggungan atau aswransi yang mersberikan jaminan scoial bagi anggots masymakat pengguna.

Asuransi kendaraan

bermotor adalah asuransi khusus sebagai pertanggungan atu asumansi apsbila kendaraan itu mendapat kecelakaan dast atua bilang sehingga memberikan jaminan kepada anggoca masyankat yang tertimpa musibah kecelakaan lalu lintas di laar kesalahannya sendiri karersa pengguna kendarsan pribadi yang ditumpanginya, bilang atau caxcutnya kendaraan adalah merupakan sualu peristima yang tidak disengaja ataupun tidak. distangka-sangka terjadi.

Di Indenesia pada saat ini dapat dikatakan baltwa kinerja perasuransian belum mengeembirakan yang mana dari pihak pengelola usaha asurafrsi belum memberikan pelayanan yang baik, bahkan sering kalk melakukan penipuan terhadsp konsumen stau muncul kesun dipersulit ketika akan thenggugat hak, baik dalam asuransi jiwa maupun dalam asuransi kerugian. Sedanekan dari pihak masyararat industri asuransi kurang dimirnati, disamping minimnys pengetahuan masyarakat terbadap asuransi, juga disebabkan masih rendahnya income per kapūta masyarakat, walaugan Asuransi kethdarnan bemolor sebagai lembaga jaminan yang dipercayakan unluk pemberian jaminan perlibduegan dirasakin semakin penting, tetapi masih terdapat anggota masyarakat yang belum memsahami peranan asuransi kendaraan bermotor dalam meringankan beban pemilik kendaraan bermoloe, seltingga pertulis menganggap perlu untuk dilakukan analisis lebih lanjut mengenai "Analixis Hukum Terhadap Asuransi Kendaraan Bermotor bagi Pemilik Kendaraan Bermotor"

\section{II.PEMBAHASAN}

A. Asuransi pada Umumnya

I. Pengertian Astaransi 
Asuransi atau dalam bahasa Belanda "Verzekering" yang berarti pertanggungan. Dalam pasal 246 Kitab Undang Undang Hukum Dagang (KUHD) atau Wetboek Van Koophandle, bahws:

"Asuransi atau pertanggungan adalah sustra perjanjian dengan mana seorang penanggung mengikatkan diri dengan seseorang tertanggung dengan menerima uang premi untuk memberikan penggantian

kepsdanya karena suatu kerugian, kerusakan atau kehilangan

keuntungan yang diharapkan yang mungkin akan didends karena suatu peristiwa tak tentu".

bagi Ketentuan ini berlaku pertanggungan, baik yang ada dalam Kitab Undang-Undang Hukum Dagang (KUHD) maupun yang ads di luar Kitab Undang-Undang Hukum Dagang (KUHD).

Dalam UU No. 40 Tahun 2014 tentang Perasuransian, Pasal 1 dejelaskan bahwa: Dalam Undang-Undang ini yang dimaksud dengan:

1. Asuransi adalah perjanjian antara dua pīhak, yaitu perusahaan asuransi dan pemegang polis, yang menjadi dasar bagi penerimaan premi oleh perusahaan asuransi sebagai imbalan untuk:

a. memberikan

penggantian kepada

tertanggung atau

penegang polis

karena kerugian,

kerusakan, biaya

yang timbul,

kehilangan

keuntungan, atau

tanggung jawab

hukum kepada pihak

ketiga yang mungkin

diderita tertanggung

atau pemegang polis

karena terjadinya

suatu peristiwa yang

tidak pasti; atau

b. memberikan

pembayaran yang

didasarkan pada

meninggalnya

tertanggung atau

pemboxyaran yang

didasarkan pada

hidupnya tertanggung

dengan manfast yang

besamya telah

ditetapkan danjatau

didasarkan padn hasil pengelolaan dana.

Terdapat 3 (tiga) unsur mutlak yang perlu diperhatikan dalam Pasal 246 Kitab Undang. undang Hukum Dagang, yaitu :

1. Adanya Kepentingan

Kepentingan adalah obyek pertanggungan dan merupakan hak subycktif yang mungkin akan lenyap atau berkurang karens terjadinya sustu peristiwa tak tentu atas pasti. Unsur kepentingan adalah unsur yang mutlak harus ada pada tiap-tiap pertanggungan, baik pada sant ditutupnya pertanggungan 
maupun pada saat terjadinya avemen.

2. Adanya Peristiwa Tak Tentu Unsur peristiwa tak tentu dalam pertanggungan jiwa, yaitu kematian adalah stuatu peristiwa yang pasti akan terjadi, dimana yang tidak tertentu adalah "kapan" kematian itu akan menjadi kenyataan. Peristiwa tak tentu dalam pertanggungan jiwa baru ada apabila si penanggung mengikatkan difi untuk membsyar, kalau kematian datang lebih pendek daripada jangka waktu dan kemungkinan berlangsungnya hidup orang yang bersangkutan. Lain halnya dengar pertanggungan kerugian sebab disana peristiwa itu adalah suatu kejadian yang menurut pengalaman manusia tidak dapat diharapkan akan terjadi.

3. Adanya Kerugian Penggantian kerugian diberikan penanggung sebenamya tidak dapat dikatakan sebagai suatu ganti rugi, olch karena orang yang menerima ganti rugi tidak menerima ganti rugi yang sungguh-sungguh sesuai dengan kerugian yang dideritanya. Ganti rugi yang diterimanya sebenarnya adalah hasil penentuan sejumlah uang tertentu yang telah disepakati pihak-pibak.

Jadi pemberian uang oleh penanggung bukanlah murni merupakan suatu penggantian kerugian, oleh karena jiwa manusia tidak mungkin dinilai dengan uang. Rumusan definisi pertanggungan dalam Pasal 246 Kitab Undang-Undang Hukum dagang (KUHD) bagi segala macem pertanggungan, dengan demikian berlaku bagi pertanggungan kerugian maupun bagi pertanggungan sejumlah Lang atau pertanggungan jiwa. Tujuan dari Asuransi atau Pcrtanggungan (Abdul kadis Muhammad 1999:8) adalah sebagai berikut :

1. Tujuan Ganti Rugi

Ganti rugi yang
diberikan oleh penanggung
kepada tertanggung apabila
tertanggung menderita tertanggung menderith
kerugian yang dijamin olch polis, yang bertujuan untuk mengembalikan tertangung dari kebangkrutan sehingga ia masih mampu berdiri seperti sebelum menderita kerugian. Jadi tertanggung hanva oleh boleh memperoleh ganti rugi sebesar kerugian yang dideritanya, artinya tertanggung tidak boleh mencari keuntungan (speklasi) dari asuransi. Bagitu juga dengan penanggung, ia tidak boleh mencari keuntungan atas interst yang ditanggungnya, kecuali memperoleh beals jasa atau premi.

2. Tujuan tertanggung Adalah sebagai berikut :

a. Untuk memperoleh rasa tentram dan aman dari resiko yang dihadapinya atas kegiatan usahanya atas harta miliknya.

b. Untuk mendorong keberanianya mengikntkan usaha yong lebih besar dengan resiko yang lebih besar pala, karena risiko yang benser itu idlambil oleh pertanggung.

3. Tujuan Penanggung

Tujean penanggung dibagi 2 (dua), yaitu :

a. Tujuan Umum, yaitu : memperoleh keuntungan selain menyediakan lapangan kerja, 



$\begin{array}{lr}\text { apabila } & \text { penanggung } \\ \text { membutihkan } & \text { tenaga } \\ \text { pembanta. } & \end{array}$

b. Tujuan Khuses, adalah :

- Meringankan resilko yang yang dihadapi oleth pars nasabah atau para tertangeung dengan mangambil alhi risiko yang dihsdapi.

- Menciptakan rasa tentram dan aman dikalangan nasabahnya, schingga lebih berani mengikatkan usaha yang lebih besar.

- Mengumpulkan dana melalui premi vang terkumpul sedikit demi sedikit dari para nasabahnya schingga terhimpan dana besar yang dapat digunakan unluk membisyai pembagian

\section{Sifut Asurnnsi} Bangsa dan Negara.

Asuransi atou petanggungan di Indonesia sebenarnya berasal dari Hukum Baras, baik dalam pengertian maupun adlam bentuknya. Asuransi sebagai bentuk hukum di Lodonesis yang diatur dalam Kitab Undang Undang Hukum Perdacs yang mempunyai beberapa sifat sebagai berikus :

\section{ง. Sifat Perjanjian}

Semus asuransi berupa perjanjian tertentu fBoyvondene Over Komst), yaitu suatu pemufaksatan antara dua pihak atau lebih dengan maksud akan mencapai sustu tujusan, dimens seorang atas lebih berjimji vethadap seorang lain atau lebih (pasal 1315 Kitab UndangUndang Hukum Perdsta). b. Sifat timbal balik (Weder Kerige)

Persetujuan asuransi arau pertangzungan merupakan suatu persetujuan timbal balik (Wedor Kerige Overeen Komal), yang berarti bahwa masing masing pihzk berjarji akan melakwkan sesuatu bagi pihak lain.

Pihak terjamin berjanji akan membayar uang premi, pihak penjamin berjanji akan membayar sejumlah uang (taang asuransi) kepada pihak terjamin, apabila suatu peristiwa tertentu terjadi.

c. Sifat Konsensual

Persetujuan asumnsi atau pertangungan merupakan suatu persetujuan yang bersifat kensensual, yaitu sudah diangeap terbentuk dengan adanya kata sepakat antara kedua belah pihak (pasal 251 KUHD)

d. Sifat Perkumpulau

Jenis ajuransi yaming bersifut perkumpulan (Vereeninging ) adalah asuransi saling menjamin yang terbentuk diantara para terjamin selaku anggota. Asuransi seperti ini distbutkan dalam pasal 286 Kitab Undang-undang Hukum Dagang (KUHD) yang menyatakan bahwn asuransi itu cakluk psda perselujuannya dan peraturannyz. Peakumpulan asuransi

diatur dalam Pasal 1635, 1654 dan 1655 Kitab Undang-undang Hukum Perdata (KUHPer), yang dapat disimpulkan bahwa perkumpulan asuransi saling menjamin merupakan "Zateliojk Liefroow" yang artinya asuransi dalam masyarakat dapat bertindak selaku orang dan dapat mengadakan segala perhubungan 
hukum dengan orang lain secara sah.

Perkumpulan asuransi dapat bertindak kedalam dan keluar, yaitu kedalam jdapat mengadakan persetujuan asuransi dengan para anggota selaku terjamin, dan keluar dengan perbuatan hukum lainnya, persetujuan ini takluk pada ketentuan Kitab Undang-Undang Hukum Dagang (KUHD), baik dengan anggota sendiri maupun dengan orang lain.

e. Sifat Perusahaan

Asuransi yang mengatur sifat perusahaan adalah asuransi secara premi dimana diadakan antara pihak penjamin dan pihak terjamin, tanpa ikatan hukum diantara terjamin dengan orang lain yang juga menjadi pihak terjamin terhadap si penjamin.

Dalam hal ini pihak penjamin biasanya bukan seorang individu, melainkan suatu badan yang bersifat perusahaan, yang memperhitungkan untung rugi dalam tindakannya.

3. Polis dan Premi di dalam Asuransi

a. Polis Asuransi

Suatu perjanjian asuransi atau pertanggungan bersifat konsensual atau adanya kesepakatan, harus dibuat secara tertulis dalam suatu akta antara pihak yang mengadakan perjanjian. Pada akta yang dibuat secara tertulis itu dinaman "polis", Jadi, polis adalah tanda bukti perjanjian pertanggungan yang merupakan bukti tertulis. (abdul Kadir Muhammad 1999. 57)

Pada perjanjian asuransi atau pertanggungan antara para pihak, seorang penanggung harus menyerahkan polis kepada tertanggung dalam jangka waktu sebagai berikut :

a. Bila perjanjian dibuat seketika dan langsung antara penanggung dan tertanggung yang dikuasakan tertanggung. maka polis yang telah ditandatangani olch penanggung harus diserahkan kepada tertanggung dalam tempo 24 jam (pasal 259 KUHD).

b. Jika pertanggungan dilakukan mulai makelar asuransi (broker), maka polis yang telah ditandatangani olch penanggung harus diserahkan kepa ia tertangung paling lama dalam tempo 8 (delapan) hari (pasal 260 KUHD).

- Fungsi Umum Polis, adalah :

a. Perjanjian pertanggungan (Contract of Indonesia)

b. Sebagai bukti jaminan dari penanggung kepada tertanggung untuk mengganti krugian yang mungkin dialami oleh tergugat akibat peristiwa yang tidak diduga sebelumnya dengan prinsip

- Untuk mengembalikan tertanggung kepada kedudukannya semula sebelum mengalami kerugian; atau

- Untuk mengindarkan tertanggung dari kebangkrutan (Toial Collapse) 
c. Bukti pembayaran premi asuransi oleh tertanggung kepada penanggung sebagai balas jasa atas jaminan penanggung.

- Isi polis pada Umumnya dalam Asuransi

Sesuai dengan peraturan Undang-Undang Hukum Dagang (KUHD), dengan pengecualian terhadap asuransi atau pertanggungan jiwa, terdapat 8 (delapan) syarat diantaranya yaitu :

a. Hari dicutupnya perjanjian pertanggun gan

b. Orang yang menutup pertanggungan, atas namanya sendiri atau atas tanggungan orang ketiga.

c. Uraian yang jelas mengenai benda pertangungan atau obyek yang dijamin

d. Jumlah pertanggungan, untuk mana diadakan jaminan (uang asuransi)

e. Bahaya-bahaya yang ditanggung oleh penanggung

f. Saat mulai dan akhir tenggang waktu, dalam mana didakan jaminan oleh penjamin.

g. Jumlah uang Premi yang harus dibayar oleh si terjamin

h. Keterangan tambahan yang perlu diketahui oleh penjamin dan janji-janji khusus yang diadakan oleh kedun belah pihak.

b. Premi di dalam asuransi Pengertian premi dalam asuransi atau pertanggungan adalah kewajiban tertanggung, dimana hasil dari kewajiban tertanggung akan digunakan olch penangung untuk mengganti kerugian yang diderita tertanggung.

Dalam UU No, 40

Tahun 2014 Pasal 1 ayat 29 dijelaskan bahwa:

Premi adalah sejumlah uang yang ditetapkan oleh Perusahaan Asuransi atau perusahaan reasuransi dan disetujui oleh Pemegang Polis untuk dibayarkan berdasarkan perjanjian Asuransi atau perjanjian reasuransi, atau sejumlah uang yang ditetapkan berdasarkan ketentuan peraturan perundangundangan yang mendasari program asuransi wajib untuk memperoleh manfaat.

\begin{tabular}{llr}
\multicolumn{2}{c}{ Premi } & biasanya \\
ditentukan & dalam & suatt \\
presentase & dari & jumlah
\end{tabular} pertanggungan, dimana dalam presentase menggambarkan perilaian penanggung terhadap resiko yang ditanggungnya, penilaian penanggung berbeda-beda, akan tetapi hal ini dipengaruhi oleh hukum permintaan dan penawaran.

Fungsi dari premi merupakan harga pembelian dari tanggungan yang wajib diberikan oleh penanggung atau sebagai imbalan resiko yang diperalihkan pertanggungan dibuat, kecuali pertanggungngan saling menanggung. Sedangkan mengenai pembayaran premi, biasanya dibayar tunai pada saat perjanjian pertanggungan ditutup. Tetapi jika premi diperjanjikan dengan anggaran 
maka pressl dibayar poda permulasn tiop-tiap waktu andsuran.

3. Subyek dan Obyek Asuransa a. Sebyek Asuransi Dalarts tiap-1isp persetujan selalu ada 2 (dus) macam subyek, yaitu di satu pitak seorartg atsa badan hukum mendzpat tadan kewajiban untuk. xesuzca, ban dilyin pihak ada scorang atau suatu bodan hukum rang mendagat hak atas pelaksanasn kewajikan itw, maka dalan tiap-tiap perselujuan selalu ała pühak berkerajiban dan pihak bertak. Dengan demikian, para pithak dzlam perjanjian pertanggungan yažtu petanggung dan tertanggung.

Jadi berdasarkan Pasal 246

Kitab Undang-Undang Hukum Dagang. (KUHD) bisa disimpulkan bahwa ads dua pihak yang berperan sebseai subyek asuransi, yoitu :

a. Pilak tertanggung, yailu pilak yang mempungai harta benda yang diancam bahaya. Palak ini bermaksod untuk menealihkan resiko atas harta betulanya, ates peralition resiko tersebut pihsk tertanggung menspunyai kewajiban unluk menbayar premi.

b. Pihak penanggung, rakni pihak yang mau menerima resiko alas harta bendz arang lain, dengan suata kontra prestasi berups premi. Dengan demikian apabila terjadio peristiws yang mengakibuckan keinginan pentadgengla yang memberi ganti nugi

b. Otyck Asuransi Pasal 1 angka 25 Undang-Undang Usaha perzsuransian discbutkan bahwa Objec $\wedge$ suransi sdalah jiwz dan ragz, kesehatan manusia, tanggung jawab hukum, benda dan jase, scrt2 scrova kepemingan lainnya yang dapat hikang, rusak, rugi. dan'alau berkurang nilainyz. Jadi ada 3 (tiza) hal yang dapat didipertanggungkan 〈obyck asuransi), yaita:

a. Risiko pribodi, yaintu kebildupan dan keselatan.

b. Hak milik aus bends

c. Tanggung jawab atau kewajibsin yang harus dipikul seseorang.

Obyek pertangeunean

dikenzl pula dengan seturan "Kepentingm". kepentitean merupakan unsur utamis dalam pertanggungan Pasal 250 Kitab Undang-Undang Hukum Dagang (KUHD) menyebutkan balwwa bila pada maktu pertiegeungan sorang tertangeung tidak mempunyai kepentitiean atas bends yang dipertangeungkan, penanggung tidak wajib memberi ganti rugi. Mengingat pentinenya obyek pertangsungan Iersebus. maka tidak setiap kepentirton dapat dipertanggungkan. Agar 4apa diprtangonekan, kepertingan yang dimaksud harus memenuhi syarat tertentu. Phisal 268 Kitab Undang-Undang Hukum Dogang (KUHIy) menyatakan, balwwa yang dapat menjadi obyek isuransi ialah semma kepenlingan yang :

a. Dupat dinilsi dengan sejumlah ung

b. Dapat disteam olch macam bahaga 
c. Tidak dikecualikan oleh undang-undang

B. Analisis Hukum dan Prosedur Klaim Asuransi Kendarnan Bermotor.

Dalam KUHD ada dua cara pengaturan asuransi, yaitu pengaturan yang bersifat umum dan yang bersifat khusus. Pengaturan yang bersifat umum lerdapat dalam Buku 1 Bab 9 Pasal 246-286 KUHD yang berlaku bagi semua jenis asuransi, baik yang sudah diatur dalam KUHD maupen yang diatur dalam KUHD. Pengaturan asuransi dalam KUHD mingutamakan segi keperdataan yang didasarkan pada perjanjian antara tertanggung dengan penanggung. Perjanjian tersebut menimbulkan kewajiban dan hak tertanggung dan penanggung secara timbal balik. Sebagai perjanjian khusus, asuransi dibuat secara tertulis dalam akta yang disebut polis asuransi. KUHD mengutamakan pengaturan asuransit dari segi keperdataan, sedangkan Undang-Undang No 40 Tahun 2014 tentang Perasuransian mengutamakan pengaturan asuransi dari segi bisnis dan publik administratif, yang jikn dilanggar mengakibatkan pengenasn saksi pidana dan administratif. Pengaturan dafi segi bisnis artinya menjalankan perasuransian harus sesual dengan aturan hukum perasuransian dan perusahaan yang berlaku, dari segi publik administrasi artnya kepentingan masyarakat dan negara tidak boleh dirugikan, jika hal ini dilanggar, maka pelanggaran tersebut dianeam dengan saksi pidana dan sasi adminstratif scbaginana yang diatur dalsm Undang-undang Perasuransian, selain itu untuk mengimbangi kebijakan ini, Pemeriblah dan/atau Otoritas Jasa Keuangan melakukan upaya untuk meadorong peningkatan kapasitas asuransi dan reasuransi dalam negeri. Undang-Undang ini juga mengharuskan penyelenggarasn Program Asuransi Wajib, misalnya ssuransi tangzung jawab hukum kepada pibak ketiga bagi pengendara kendaraan bermotor, secara kompetitif dan memungkinkan pemberian fasilitas fiskal kepada perscorangan, rumah tangga, dan/atau usaha mikro, kecil, dan menengah untuk mendorong peningkatan pemanfaatan Asuransi atau Asuransi Syariah dalam rangka pengelolaan risiko. Pengaturan lebih lanjut yang diamanatkan Undang-Undang ini kepada Otoritas Jasa Keuangan, terutama dalam hal pengaturan lini usaha dan produk Asuransi dan Asuransi Syariah serta pengaturan pengeiolaan kekayaan dan kewajiban Perusahoan Asuransi, Perusahaan Asuransi Syariah, perusahaan reasuransi, dan perusahaan reasuransi syariah, akan menentukan besar atau kecilnys peran industri perasuransian tersebut. Pengaturan dalam UndangUndang ini juga mencermiakan perhatian dan dukungan besar bagi upaya pelindungan konsumen jasa perasuransian, upaya antisipasi lingkungan pcrdagangan jasa yang lebib terbuka pada tingkst regicaal. 
dan penyesuaian terhadap priktik terbaik (bess practices) di tingkat internasional untuk penyelenggaraan, pengaturan, dan pengawasan industri perasuransian.

Dalam Peraturan Menteri Keuangan (PMK) No, 74/PMK.010/2007 khususnya

Pasal 1 ayat (2) : "Asuransi Kendaraan Bermotor adalah produk asuransi kerugian yang melindungi tertanggung dari resiko kerugian yang mungkin timbul sehubungan dengan kepemilikan dan pemakaian kendaraan bermotor". Asuransi

Kendaraan

Bermotor merupaka: bagian dari asuransi umum yang menjamin kerugian atau kerusakan pada kendaraan bermotor yang dipertanggungkan terhadap resiko tabrakan, perbuatan jahat orang lain, pencurian, kebakaran dan sambaran petir, sesuai dengan kondisi yang tercantum dalam Polis Kendaraan Bermotor Indonesia. Secara garis besar, jenis pertanggungan Asuransi Kendaran Bermotor terbagi menjadi 2 (dua) yaitu dibagi menjadi 2 (dua) jenis:

1. Comprehensive/All Risk

(Kerugian

memberikan jaminan tethadap:

a. Kerugian/kerusakan atas kendaraan bermotor yang diasuransikan karena tabrakan, benturan, terbalik, tergelincir dari jialan.

b.

Kerugian keuangan/kerusakan

kendaraan bermotor karena perbuatan jahat orang-orang terkecuali olch keluarga

sendiri/orang yang bekerja dengan tertanggung atau membawa kendaraan

tersebut seizin

tertanggung atat

membawa kendaraan

tersebut seizin

tertanggung.

c. Kebakaran yang

diakibatkan oleh api yang

muncul dari dalam

maupun dari luar

Kendaraan.

d. Pencurian, termasuk pencurian yang dilakukan dengan kekerasan.

c. Sambaran petir.

2. Total Loss Only (TLO) menjamin kerugian

kendaraan yang diasuransikan baik karens kecelakaan, kebakaran, maupun pencurian, dimana kerugian tersebut memenuhi salah satu syarat berikut

kecelakaan/kebakaran,

dimana biaya

kerugian/kerusakan mencapai $75 \%$ atau lebih dari harga kendaraan.

b. Akibat pencurian, bila dalam batas waktu 60 hari kendaraan tersebut belum diketemukan.

c. Resiko sendiri untuk resiko kecelakaan (butir 1) dan pencurian (butir 2) berlaku

d. jumlah yang tercantum dalam polis

Dalam Polis Standar

Kendarasin Bermotor

Indonesia yang diterbitksn

oleh Dewan Asuransi

Indonesia, pada umumnya polis ini menjamin kerugian 
atau kerusakan kendaraan bermotor yang disebabkan antara lain oleh:

1. Tabrakan, benturan, terbalik tergelineir atau terperosok

2. Perbuatan jahat orang lain.

3. Pencurian termasuk pencurian yang didahului atau disertai dengan kekerasan atau ancaman

4. Kebakaran akibat sambaran petir

5.Kerusakan selama kendaraan dalam penyeberangan menggunakan feri yang dikelola oleh Dirjen Perhubungan Darat

6. Biaya Derek.

Polis asuransi kendaraan bermotor juga menjamin risiko tanggung gugat (tanggung jawab hukum tertanggung kepada pihak ketiga.) dimana pihak ketiga mengalami kerugian yang secara langsung disebabkan oleh kendaraan bermotor yang diasuransikan dengan syarat telah mendapat persetujuan tertulis dari penangggung. Kerugian yang diderita pibak ketiga dapat berupa kerusakan harta benda atau cedera badan atau kematian. Termasuk pula dalam risiko tanggung gugat yang dijamin adalah biaya perkara atau biaya bantuan para ahli yang telah disetujui lebih dulu oleh pihak asuransi. Sedangkan resiko yang tidak dijamin berdasarkan Polis Standar Kendaraan Bermotor Indonesia yang diterbitkan oleh Dewan Asuransi Indonesia antara lain:

1. Kehilangan keuntungan selama kendaraan tidak dapat di gunakan akibat kecelakaan

2. Kerugian alkibat penggelapan

3. Hilangnya atau rusaknya peralatan tambahan atau non standar yang tidak disebutkan dalam ikhtisar polis

4. Akibat perbuatan jahat yang dilakukan oleh tertanggung atau keluarga tertanggung

5. Kendaraan digunakan untuk belajar mengemudi atau perlombaan atau kamaval, atau tindak kejahatan

6. Kelebihan muatan

7. Pengemudi tidak memiliki SIM atau melanggar peraturan lalu lintas

8. Barang muatan di dalam kendaraan

9. Akibat bencana alam atau perang dan sejenisnya.

Adapun prosedur pengajuan klaim kendaraan bermotor jika terjadi kerugian akibat kecelakaan atau kehilangan

1. Melapor kepada penanggung dalam jangka waktu maksimum 72 jam setelah kejadian.

2.Tidak diperbolchkan mengambil tindakan apapun sebelum mendapat persetujuan dari Perusahaan Asuransi.

3. Menyiapkan dokumendokumen yang diperlukan:

a, Nomor polis asuransi

b. Tempat kejadian

c. Nama pemilik polis 
d. Kenıgian benda

e. Merek kendaraan

f. Nomor polis kendaraan jadinya kecelakaan

g. Tanggal kejadian kerugian

Untuk dokumen-dokumen Klaim yang diperlukan:

1. Mengisi formulir klaim

(formulir dapat diminta)

3. Foto copy polis asuransi

4. Foto copy SIM dan STNK

5. Surat keterangan polisi setempat (B.A.P.)

Untuk klaim kendaraan jika kehilangan perlengkapan standard I non standart maupun kchilangan kendt.raan dan juga jika kendaraan menjalami rusak berat atau menyangkut pihak ketiga. Khasus klaim kehilangan kendaraan atau Kerusakan total dokumen yang diperlukan adalah:

1. STNK asli

2. Kunci kontak kendarasan.

3. Surat keterangan Kanit Reserse Polda

4. BPKB asli dan faktur

5. Blanko kwilansi kosong rangkap tiga

6. Pemblokiran STNK

Khusus klaim yang melibatkan tanggung jawab hukum terhadap pihak ketiga (third parny Liability). Jika nasabah mengalami kecelakaan yang melikatkan kerugian pada pihak ketiga (TPL) dan nasabah dituntut untuk mengganti kerugiannya, maka nasabah harus meiengkapi dan menyerahkan dokumendokumen sebagai berikut :

1. Surat keterangan polisi setempat (Berita Acara Pemeriksaan)

2. Foto copy STNK dan SIM dari pihak ketipa

3. Surat tuntutan dari pihak ketiga yang ditandatangani diatas materai
4. Foto kerugian materi dari pihak ketiga.

Kontrak yang dituangkan dalam bentuk polis sebagai suatu kontrak, maka ketentuan-ketentuan yang diatur didalamnya tidak boleh merugikan kepentingan pernegang polis. Untuk melindungi kepentingan masyarakat luas, penetapan tingkat premi harus tidak memberatkan tertanggung, tidak mengancam kelangsungan usaba penanggung. dan tidak bersifat diskriminatif.

\section{IIL. Penutup}

Pertanggungan atau asuransi adalah suatu perjanjian, dimana penanggung menerima premi dari pilak tertanggung sebagai transaksi ditutupaya perjanjiar asuransi kendaraan bermotor pada suatu peristiwa yang tak tentu terjadi. Setiap orang yang memiliki kendaraan bermotor baik roda dua atau lebih pasti menghadapi resiko bahwa nilai dari miliknya itu akan berkurang baik karena hilangnya atau cacat dan rusaknya kendaraan bermotor atau sebab-sebab yang lainnya. Resiko adalab kewajiban menanggung atau memikul kerugian sebagai akibat dari suatu peristiwa diluar kesalahannya, yang menimpa kendaraan bermotor yang menjadi miliknya. Besamya resiko tersehut dapat di ukur dengan nilai kendaraan yang terkena bahaya dan hal ini tentu saja merugikan pemiliknya. Makn makin besar kendaraan bermotor yang dimiliki seseorang makin besar pula resikony'a menghadapi hilang, rusak, atau tabrakan dalam kecelakaan, hal ni merupakan suatu teknik asuransi 
Pleno De Jure, Vol 4, No. 5. Desember 2015

yang membutuhkan penyelidikan secarn ilmiah dengan menggunakan statik. Besamya premi ditetapkan secara prosentase dari jumlah uang yang dijamin dan dihïtung scodemikian rups, sehingsa dengan penerimasn premi itu penanggung dapst mentperhitungkan dengan kemamopuannya untuk mengganti kerugian kepada tertanggung bila tertimpa suata kerugian.

Kendala yang sering terjadi pada asuransi seringkali pihak penanggung (perudahasan asuransi) mempersulit dalam pengajuan klaim oleh tertanggung Maka untuk itu diperlukan pengetahuan yang lebïh lanjut mengenai pola kerjasama ini baik bagi calon tertanggung maupun perusahaan asuransi. Dalam rangks pembinaan dan pengawasan, peraturan pelaksanaan yang mencakup masalah penyelesaian klaim, jika terdapat itikad tidak baik dari penangesung maks tertanggung dapat melaporkan kepada lembaga penpatur dan pegawasan yang dilakukan oleh Otoritas Jasa Keuangan sebogaimana yang diatur dalan Pasal I anagka 35, UndangUndang Perasuransian bahwg Oworitas Jasa Keuangan ndalah lembaga pengalur dan pengawas sektor jasa keuangan. juga distur dalam Pasal 57 (1) Undang. Undang Perasuransian bahwa Pengaturan dan pengawasan kegiatan Usaha Perasuransian dilakukan oleh Otoritas Jasa Keuangan.

\section{DAFTAR PUSTAKA}

Abdul Kaslir Mubammad. 1999. Hukam perasuransian. PT. Citra Aditya Bakti, Bandung.

C.S.T, Kansil. 2001. Hukwm Perusahnan Indonesia. PT. Pradnya Paramita, Jakarta

Desmati Saharuddin. 2015 . Pembayaman Ganti Rugí padka Aswranvi Syariah. Prenada Media Groug. Jakarta.

J. Tinggi Sianipar. 1999. Aruranes Pengankasan Laur (PrinsipPrinasp Polok dalam Mcioksanakan Penutupan dan Pengarsesan Klow Asuransi. Jakarta.

Muhammad Muslehuddin. 1999. Mengugat Asuransi Sumber Lain:

Kitab Undang-Undang Hukum Perdata (KUHD)

Undang-Undang Nomor 40 Tahum 2014 tentang Perasuransian. 
